\title{
'LONG TERM IMPACT OF INDUCED DISPLACEMENT AND RELOCATION ON ADOLESCENCE; WITH A FOCUS ON WELLANGIRIYA AREA, SRI LANKA'
}

\author{
Udari Samarakoon* \\ University of Colombo, Sri Lanka \\ Email:*udasuba123@gmail.com
}

\begin{abstract}
All most all of the large scale development project create victims and beneficiaries in large number. Number of people are induce displace or involuntary displace from their houses due to such development projects. Improper planning in displacement and relocation can lead to both longterm and short-term negative consequences for the entire society. Every group in the induced displace community should be considered in relocating, one such group that should be focus on, is the adolescents of the displaced community. It is important to understand whether dramatic changes took place within environment surrounding them actually influence their lives.

This study was conducted in Wellangiriya in Colombo District. During 1977 people who lived in slums and shanties in Narahenpitaarea were induced displaced because of large scale urban beautification and development project in Colombo area. Objective of the study was to understand how adolescents (during 1977) coped up with the induce displacement and relocation process, and understand how that influence to shaped up their current lifestyles. As for data collection both quantitative and qualitative data were gathered using different techniques such as, interview methods, questionnaires and focus group discussions.

Study revealed that changes took place due to induced displacement and improper relocation influenced them as adolescents in various ways and as mid age people they still have to deal with results of relocation. Thus this study shows that unplanned displacement and relocation will create beneficiaries for sure but it might also create number of victims too.
\end{abstract}

Keywords: relocation, improper planning, adolescents, coping, livelihood, education

\section{Introduction}

In Sri Lankan, when it comes to development related induce displacement there are few significant cases, such as, Hydro electricity generation plants, Irrigation schemes and agricultural extensions. According to Fernando and Punchihewa (2013) the most recent development induced displacement happened, due to Southern Transport Development Project.1, 338 families had to move from their habitat.

During 1980 -Parliament of the Democratic Socialist of Sri Lanka brought an Act named Urban Development Projects (Special Provisions) Act No.2 of 1980.(Attachment 1).According to this The President of Sri Lanka has the power to gain any land within the country with the recommendation of the Minister in charge of the subject of the Urban development. Thus as a result of Mega Urban Beautification project conducted from 19761979 thousands of Urban dwellers were relocated from Urban to suburb areas. 
In 1978 Master plan for the Colombo metropolitan area ${ }^{1}$ consisted with two main city plans, namely Colombo Metropolitan Regional Structure plan and Colombo Urban area plan.

During 1977 as a result of Master plan for the Colombo metropolitan area project which conducted in order to demolition of poverty districts such as slums and shanties and expansion of urban area, People who lived in Narahenpita area were resettled in Wellangiriya area. Wellangiriya area is situated in Colombo district HokandaraGramaNiladari Division. According to oral statements of respondents more than three hundred families were relocated in Wellangiriya. However other than providing cash compensation based on country's policy and regulations related to land, no other rehabilitation measure were provided to affected households. In many cases involuntary displacement has had adverse impact to the livelihood of the displaced population, especially where only cash compensation is used as a means to re-establish the disrupted livelihood.

Objective of the study was to understand how adolescents (during 1977) coped up with the induce displacement and relocation process, and understand how that influence to shaped up their current lifestyles. Other than that therewere two sub objectives, first to understand and analyze the education situation in 1970s- the period during which induced displacement and relocation occurred. Secondly to find out long-term impacts of induced displacement and relocation on current livelihood and socio-cultural background of this group of people.

\section{Literature Review}

As for literature review researcher focused on concepts such as Thayer Scudder's Conceptual model on the stress and settlement process, Michael Cernea's Impoverishment Risks and Reconstruction Model for Resettling Displaced Populations (IRR model) , Howard Saul Becker's (1960) - Deviance and labeling theory and Neighborhood affects theories.

\section{Thayer Scudder's Conceptual model on the stress and settlement process.}

Thayer Scudder's Conceptual model on the stress and settlement process discuss psychological, social and cultural dimensions of stress that resettles had to cope when they displace and relocate in a whole new place. There are four different stages, Stage one - Planning and recruitment.

This start with pre-settlement period. Which started the process of planning the relocation, removal, rehabitation and development of people. Scudder shows it is important to involve displaced-people in the process of decision making and planning the process. By doing those, people will gain some kind of secure feeling about their future than just moving without any sort of idea about the project. It will reduce their stress.

Stage two - Coping adjustment.

Scudder called this stage as the most "painful stage" in the process of relocation. This start as soon as the removal process commenced. During this period of time relocatees have to go through multidimensional stress adopting to new circumstances in their lives such as; adjusting to the new environment, new neighbors, and new economic activities and host population. Scudder highlight that since these people have to go through such problems, policy makers shouldn't expect rapid development within this particular stage.

\footnotetext{
${ }^{1}$ Colombo is the commercial capital and most urbanized city in Sri Lanka. Due to urban migration, with people seeking better job opportunities, the low income and lower middle-income population has increased rapidly. This has resulted in unplanned and unauthorized informal settlements, mainly occupying urban areas with high commercial values. The government had implemented several housing policies to overcome this problem. Therefore, government has under taken different solutions like on site/ off site resettlement, and resettlement in high-rises through institutions like National Housing Development Authority, Urban development authority, Real Estate Exchange Limited (Munasinghe 2013).
} 
Stage three - Community formation and economic development.

At this stage resettlers try to risk-taking behaviors in order to invest children's education, small business and other assets. They try to develop their living standard, by buying new items, new furniture to their houses.

Also they try to create new community based activities. By doing all those things will not only improve their living standard of their lives but also minimize their dependency syndrome.

Stage four -Handing over and incorporation.

This period involves the second generation of resettlers. When there is a successful integration relocate population in to national political and economy will bring an end to the relocation process. Scudder shows the importance of handing over assets to settlers. Moreover, he states the importance of continued improvement of the living standard of the second generation of the resettles, at least in line with the neighboring areas.

Michael Cernea's Impoverishment Risks and Reconstruction Model for Resettling Displaced Populations (IRR model)

Similar to Scudder's model, the IRR model also focuses primarily on forced relocation of communities as a result of development projects.

Using this model, Cernea argues that displaced people have a risk of economic, social and cultural impoverishment when they settle in new locations, and the challenge of managing the social actors engaged in resettlement and reconstruction, namely, government officers, decision makers, social researchers, implementation agencies and other parties involved to prevent them. If this is not the case, this will no doubt this pave the way for a negative outcome of resettlement. It would however be impossible to prevent every single adverse effect of resettlement.

According to Cernea this model can be used as a planning and monitoring tool. For example, when studying the cumulative effects on resettlers, irrespective of the reason for displacement (i.e. conflict, disaster or development), it is critical to acknowledge the fact that most of them have to confront similar social and economic risks that led to impoverishment.

One or more risks may not be experienced by some resettlers owing to the characteristics of the sector (i.e. urban or rural), season of displacement and site. However, some new site specific risks could occur. Considering the general pattern, eight important possible risks which influence one another, are discussed in this model. In addition, the importance of how to overcome or prevent such risks that cause impoverishment when resettling displaced people in new settlements are also discussed.

\section{Howard Saul Becker's (1960) - Deviance and labeling theory}

Labeling theory picks up on a Durkheimian conception, though developing it to very different effect: deviance is very much a public matter, and deviants, as they have traditionally been studied, are people who have been publicly identified as such, i.e. they have been taken through the courts, the psychiatric admission process and so on. The difference between deviants and normal is not, then, in their individual characteristics. The difference between them is how they have been treated by, broadly, the agencies of social control, i.e. the various administrative bodies engaged in enforcing social rules. The difference between a deviant and a supposed normal may result from how they are treated by the officials of those administrative agencies. 
A common wayto differentiate deviant from normal was to focus on characteristics-biological, psychological or social—which distinguish 'deviants' from 'normal'. However such assumption would not appeal to symbolic integrationists (E.C.Cuffet al. 2006).

\section{Neighborhood affects}

Neighborhood are consider as very important social context for children and adolescents, mainly because they provide access to resources, opportunities and interactions that influence development ( Sampson, 2000).As earlier mentioned in Thayer Scudder's Conceptual model on the stress and settlement process displaced and relocated community may have to go through several stress for very long time period, as Downing (2002) highlight induce displacement can cause to 'new poverty' while it makes poor people may become even poorer (Pandey 1998; Aronsson 2002, Martha and Marsden 1998). Thus neighborhood which goes through such radical changes will eventually affect these children and adolescent's lives within the community. Especially adolescents who grow up with less role models, weakened social institutions and social isolation from job network will lead to negative consequences (Wilson, 1987; Massey and Danton,1989)

\section{Research field}

Wellangiriya area is situated in Colombo district HokandaraGramaNiladari Division. It includes areas namely, Wellangiriya, PunchiWellangiriya, Koraya State and Sinhapura. During 1977 people lived in Narahenpita area were induced displaced because of development project in Colombo area. They were resettled to three areas, Mattakkuliya, Kahathuduwa and Wellangiriya( Hokandara).

More than 300 families were moved to Wellangiriya in 1977. All the household heads were given 10 perch land however received their land deed during 1990s. According to respondents they were only given LKR 300/= compensation from the government. German NGO Deswos has built hundred houses for these people and another fifty houses were built by Lions club.

According to Malabe Divisional Secretariat (2012) there were 4333 Sinhalese, 235 Sri Lankan Tamils, 14 Indian Tamils, 21 Burger and 35 Muslims. Though the majority of the Wellangiriya residents are second and third generations of those resettled people there are considerable number of new settlers within the area. Many people from outside the urban area have bought lands and houses within Wellangiriya area. Main reason for this is, this land is located just $12 \mathrm{~km}$ away from Colombo metropolitan area.

Gathereddata clearly shows that accessing to higher education and even for secondary education is poor within the area.

According to Malabe Divisional Secretariat (2012) and Thalangama Police Station Crime Reports (2014) Wellangiriya area is often report with many social problems such as; drug addiction, Teenage marriages and many other social problems. 


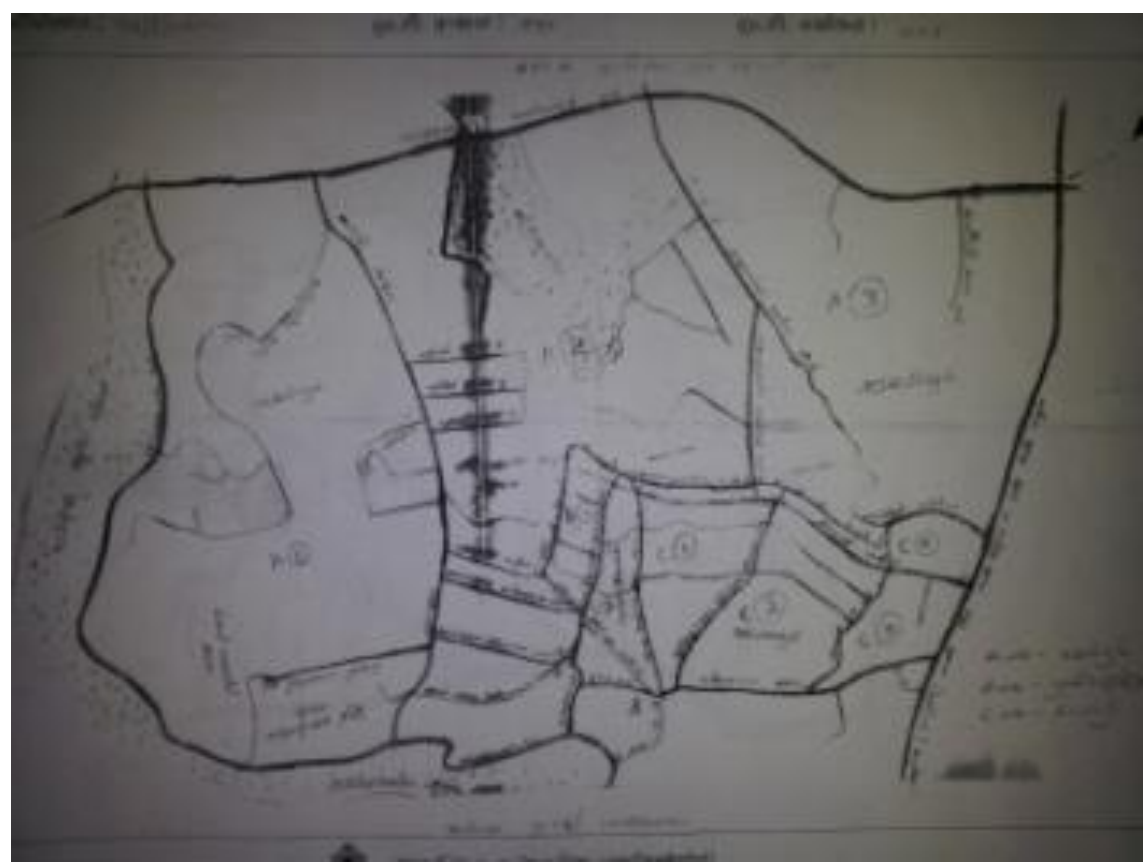

Map 1: Study Location

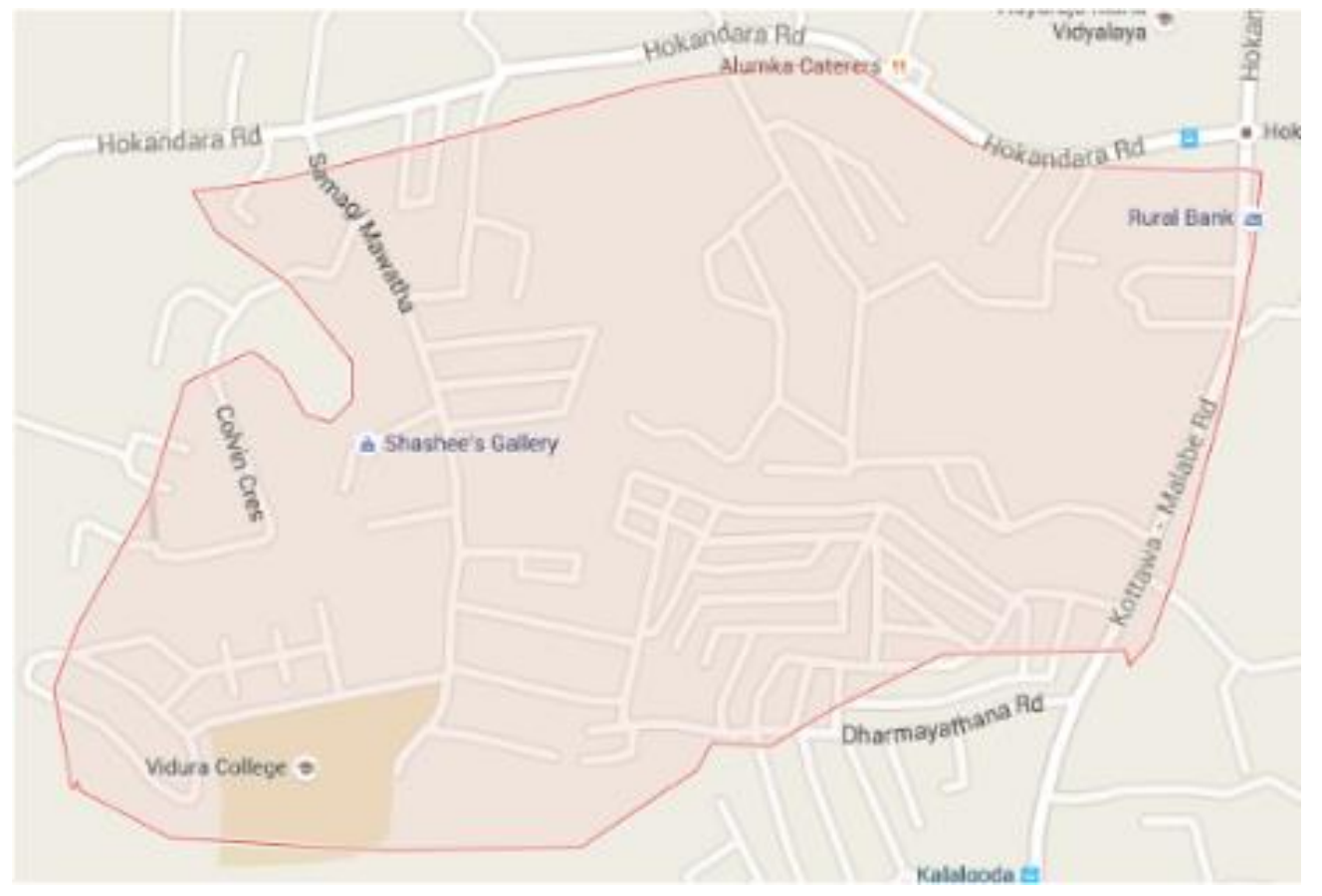

Map 2: Study Location; Google view

Source; Divisional Secretariat-Malabe, 2012

Source;Google maps, 2016

\section{Results}

Once these people displaced from Narahenpita, they were resettled in Wellangiriya, land that located in Hokandara South. During that time half of the land was covered with rubber plantation (Divisional Secretariat Malabe, 2012). The first cash compensation installment was given to them before relocating in Wellangiriya. According to Shriyani (age 66) member of Wellangiriya association of senior citizen, that they got three 
hundred rupees and this cash compensation was used for their daily necessities rather than buying materials to build houses.

The first cash compensation installment was given to them before relocating in Wellangiriya. According to Shriyani (age 66) member of Wellangiriya, that they got three hundred rupees and this cash compensation was used for their daily necessities rather than buying materials to build houseshad financial background to build a shelter. For months they have lived under trees by building shelters using polythein. One of major risk of displacement is homelessness. As Downing (2002) says for some people this homelessness may be a temporary one but for poor people it may remain chronic. As Cernea (2000) further discusses homelessness is related to other risks such as joblessness, marginalization and morbidity. Therefore homelessness cannot discuss as a separate situation but as a one major problem within the community. This was proved by respondent's following statement.

'Yes we did lived in slums but we had shelter above our heads, at least we knew we are safe, even though we used common toilets and common water pipes at least we had toilets and safe water. But once we moved to here we had nothing. Nothing except the hope, that government will help us to build shelters. Until months we kept our hopes but then realized we are on our own'.

(Respondent statement, 2015)

Empirical studies about induce displacement and resettlement shows that most of community children have to come up with many difficulties within first phase of resettling process, that will effect to their formal education, some children never return to school and join labor force at early age (Downing, 2002).

When these people lived in their previous settlement Narahenpita, they were enrolled in two schools. Veluwanavidyalaya ,Parakkramabahuvidyalaya both schools located in Dematagoda ( $13 \mathrm{~km}$ away from Wellangiriya).

After resettled in Wellangiriya because of travelling difficulties, children of these resettled families were transferred to VidyarajaMahaVidyalaya, secondary school that situated in Hokandara town (1 km away from resettled place).

By looking at education qualifications it shows that before moving to Wellangiriya and after resettling there until for two decade their education has not developed for the better. Statistics shows that there is significant number of school drop outs (especially after Ordinary Level) recorded in the community.

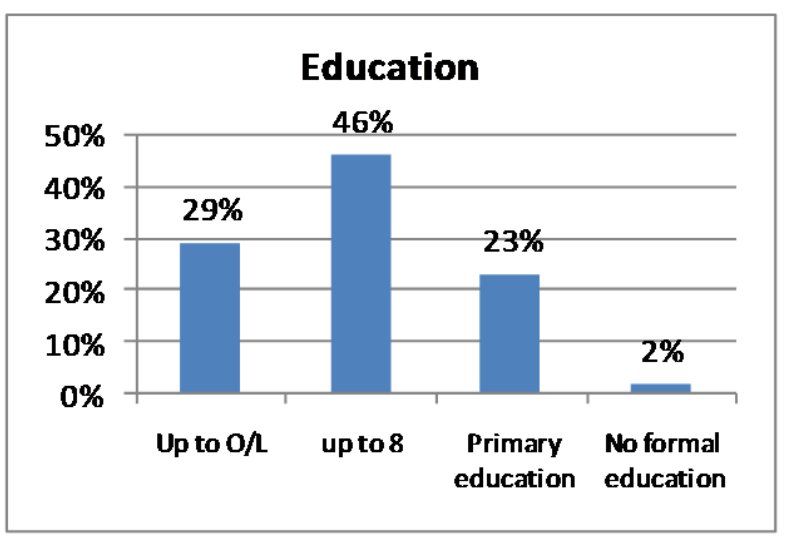

Chart 1: Education statistics of 40 years and above 
Gathered data shows that people within age 42-50 (present age) drop out from school either in grade 8 or after ordinary level. By analyzing this it shows that this group was the teenage and adolescent group who had went through process of displacement and resettlement. As Collective socialization theory shows

Neighborhood do indirectly affect children's lives, theory further

argues that especially those children who grows up with few successful adult role models(see chart1 for adults education attainments) will have low expectations of themselves. This proves with this data, since these children met few successful role model what majority of them want was somehow earn money. Another notable statement made by few respondents was that, they felt neglected and different in new school. Other children were from host community, whose parents made many conflict with their parents. In such context they were labelled as 'wattekatiya' people from slums' not only from children but also even from some teachers, and still after 37 years Wellangiriya area is known as 'watta.'. This shows how labelling can lead to negative consequences, especially this was one major reason for school dropout which on the other hand

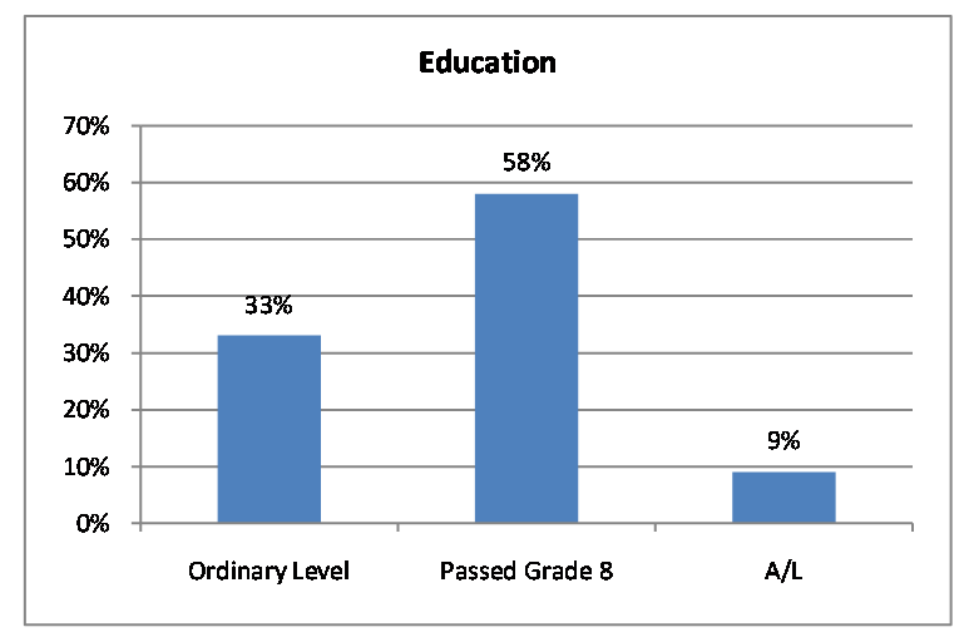

Chart 2: Respondent's Education (age 42-50).

When further questioned they mention that even during those economically and socially difficult period their parents wanted them to go to school and have formal education. But most of them showed that as teenagers they found it rather difficult to adapt to new circumstances. Wimala (age 47) states that by looking at their parents struggling with the social and economic life, what they wanted is to assist their parents, both economically and socially. As a result of it many of them have drop out from their school education and started to engage in different kind of income earning activities. However they emphasize that their parents never encouraged them to drop out from schools and it was their decision to do so. They also mentioned that they felt some kind of relief once they become independent and also since it increased the economic condition of the entire family.

As study shows during their early phase of resettlement they had to went through many of the risks which mentioned by Cernea in his IRR model, they have to went through homelessness, marginalization, loss of access to common property resources, food insecurity and other major health risks mainly increasing morbidity and mortality. It shows within that period decision makers, implementation agencies and other government officers have not paid attention about improving their life standard except giving cash compensation. Improper resettlement planning has led these poor people to poorer situation. And it has increased the vulnerability among the community mainly children, By going through all of the above details in the study, it shows that long-term poverty created by poor planning of induced displacement still effect not only economic and social lives but future lives of children within the community. Another thing noticed by the researcher is that these people are 
mainly labeled as deviants from agencies of social control, i.e. the various administrative bodies engaged in enforcing social rules.

As Downing and Downing (2009) discuss in dissonant culture, as a result of this induce displacement these people's social life became chaotic, uncertain and unpredictable and then marginalization as lower status people from host community. Those who work as daily paid workers had become unemployed and all of them have lost their routine life styles.

Low expectation, labeling as deviants and negative role models are some reasons for reducing educational achievements in the area. Another thing noticed by the researcher is that these people are mainly labeled as deviants from agencies of social control, the various administrative bodies engaged in enforcing social rules. Data further showed that not having successful role models, parent's economic situation and other numerous problems faced during second phase of the resettlement led these adolescents to give up their education and assist their parents.

This situation directly link with current economic situation of the community. Having low level educational achievements made them to end up with unstable earning methods such as small scale business or working as taxi drivers.

\section{Conclusion}

Overall results of the study showed that unplanned relocation can cause negative consequences. It made these people marginalized, homeless and unable to access the resources.

Improper planning made many of them unemployed, which worsen their economic conditions. Once adolescents felt the pressure of it and many believed that they are grown enough to engage in income earning activities. Being economically independent during that phase gave adolescents chance to assist their parents since it increased the economic condition of the entire family. However it also made them low educated population, since they were unable to enter to formal sector or secure sector of employment, thus became either informal employers or self-employers.

This proves that in the process of development none of the categories within the community should be neglected. Finally study revealed that changes took place due to induced displacement and improper relocation influenced them as adolescents in various ways and as mid age people they still have to deal with results of relocation. Thus this study shows that unplanned displacement and relocation will create beneficiaries for sure but it might also create number of victims too.

\section{Acknowledgements}

I should thank Dr Nishara Fernando for his supervision. And community members for their support throughout the research process. Also I should remind every other person helped me in this research.

\section{Reference}

Afanasyeva, A 2013, Forced relocation of the Kola Sami people: background and consequences, Universitetet.ITromso, $\quad$ Norway, $\quad$ viewed $\quad 1^{\text {st }} \quad$ January, 2015 , http://munin.uit.no/bitstream/handle/10037/5241/thesis.pdf?sequence=2.

Arachchige, Don N. S 1994, Patterns of Community Structure in Colombo, Sri Lanka. University Press of America, America.

Cader A.A and Gunathilake N, 2004, Urban Poverty in Sri Lanka. Colombo: A Center for Poverty Analysis (CEPA) Publications, Colombo. 
"CHAPTER III - FUNDAMENTAL RIGHTS." The Constitution of Sri Lanka. n.d. http://www.priu.gov.lk/Cons/1978Constitution/Chapter_03_Amd.htm (accessed September 24, 2014).

Cuff E.C,.Sharrock W.W,Francis D.W, 2006, Perspectives of Sociology, Routledge ,New York.

Curley, M. A 2005, 'Theories of Urban Poverty and Implication for Public Housing policy'. Journal of Sociology and Social welfare, Vol. 32.

Downing, Theodore E 2002, Avoiding New Poverty:Mining induced displacement and Resettlement, World Business council for sustainable development, Landon.

Fernando N 2006, Vulnerability to Poverty and Livelihood Strategies :The Case of an Urban Low Income Settlement.2006. Unpublished.

Fernando N 2004, Forced relocation after Indian Ocean Tsunami 2004,Case study of Vulnerable population in three location settlements in Galle,Sri Lanka, UNU-EHS ,Bonn, viewed on $29^{\text {th }}$ March 2015, http://hss.ulb.unibonn.de/2010/2073/2073.html

Fernando, N and Punchihewa I.A.G 2013, Relocating the displaced strategies for sustainable relocation, Friedrich Ebert Stiftung, Colombo.

Fernando, P., Karin, F. and Kumarasiri, M (ed) 2009, Forced to Moved: Involuntary Displcement and Resettlement- policy and practice, first ed., Cataloguing Publication Data, Colombo.

Ganguly, J.B 1995, Urbanization and Developmnt in North East India, Deep and Deep Publications, New Delhi. Gennetian, Sciandra, Sanbonmatsa 2012, 'US Department of Housing and Urban Development; The long Term Effects Moving to Opportunity on Youth', Journal of policy Development and Research, Vol.14, pp

Hanwella, R and Silva, V 2012, Handbook of Clinical Psychiatry; A practical Guide, Kumaran Book House, Colombo.

Harding, J.D 2003, Counterfactual Models of Neighborhood Effects: The Effects of Neighborhood Poverty on Dropping out and Teenage pregnancy, The University of Chicago, Chicago.

Hettige, S and others, 2004, Improving Livelihood of the urban poor, study of resettlement schemes in Colombo Sri Lanka, GTZ Sri Lanka in Collaboration with participatory Improvement of Underserved settlement of Colombo Municipal Council (PRIMUSS), Colombo.

Internal Displacement Monitoring Centre. Annual Report (IDMC). Review report,2001, Châteleine (Geneva): Internal Displacement Monitoring Centre, 2014.

Jayathunga, N 2012, Teenage Pregnancy and Negative Outcomes: With Special Reference to Elapatha Medical Officer of Health (MOH) Area in Rathnapura District, Proceedings of the Abstracts of Jaffna University International Research Conference, Viewed on $15^{\text {th }}$ April 2016, http://www.jfn.ac.lk/juice2012/papers/TrackE/JUICE12-TrackE-pg97.pdf

Julita. Difference between Urban and Suburban. Viewed on $6^{\text {th }}$ August 2014 http://www.differencebetween.net/miscellaneous/difference-between-urban-and-suburban/ .

Munasinghe, N 2013, A Study on Planning Stages of Urban Resettlement (With special Reference to Chithra lane Resettlement Project: Colombo Sri Laka.), Proceedings of the Third International Symposium; SEUSL, Oluvil, $\quad$ viewed $\quad$ on $20^{\text {th }} \quad$ April 2016 , http://www.seu.ac.lk/researchandpublications/symposium/international/2013/Social\%20Sci/A\%20Study\%20on $\% 20$ Planning\%20Stages.pdf.

Mwanakomba, M 2010, Impact of Development-Forced Displacement on Household Livelihood: Experience of people from Kurasini, HIS, Rotterdam.

Oucho, J 2005, INTERNAL DISPLACEMENT OF POPULATION IN THE SADC REGION, African Population and Environment Institute, Gaborone, Botswana.

Pillai S.D. and Desai A.R 1995, Slums and Urbanization. Popular Prakashan, Bombay.

Police Station Talangama, Crime Branch Report, 2014.

Rayhan, Damas Philips and Md.Israt 2014, Vulnerability and Poverty; what are the causes and how they are related, Universitat Bonn, Bonn.

Sarvimak, M., Uusitalo, R. and Jantti, M 2009, Long Term Effects of Forced Migration, IZA, Bonn.

Oliver-Smith, A(ed) 2009, Development and Dispossesion; The crisis of forced displacement and Resettlement, School for Advanced Research Press. 
Phiona, N 2011. An assessment of the Impact of a government Involuntary relocation and resettlement program on the livelihoods of development - induced displaced population; A study of Bujagali Hydropower Dam project affected people in Naminya resettlement village Uganda, Centre for development and Emergency practice (CENDEP) school of the built environment oxford Brooks University. Uganda.

Sriskandarajah, D 2003, Sri Lanka Forced Migration. Texas.

Sum, A., Khatiwada, I and McLaughlin, J 2009, The consequences of dropping out of high school; Joblessness and Jailing for high school dropouts and the high cost for Taxpayers, Center for Labor Market Studies, Boston

Terminski, B 2013, Development-Induce Displacement and resettlement: Theoretical Frameworks and current challenges, University of Geneva, Geneva.

Tessema, B.T 2001, Social, Economic, and Ecological Effect of Relocation Arkwasiye Village from Simien Mountain National Park, University of Klagenfurt, Ethiopia. Klagenfurt.

United Nations, 2016, The Universal Declaration of Human Rights, viewed on 16 ${ }^{\text {th }}$ April, 2016, http://www.un.org/en/universal/-declaration-human-rights/.

United Nation Development Program 2013, Asia-Pacific Issue Brief series on Urbanization and Climate change No.1; Addressing Urban poverty, Inequality and vulnerability in a warming world, UN-HABITAT, Thailand. 